\title{
H3F3 mutation status of giant cell tumors of the bone, chondroblastomas and their mimics: a combined high resolution melting and pyrosequencing approach
}

Thibault Kervarrec $^{1}$, Christine Collin ${ }^{2}$, Frédérique Larousserie ${ }^{3}$, Corinne Bouvier ${ }^{4}$, Sébastien Aubert ${ }^{5}$, Anne Gomez-Brouchet ${ }^{6}$, Béatrice Marie ${ }^{7}$, Elodie Miquelestorena-Standley ${ }^{1,8}$, Louis Romée Le Nail ${ }^{9,10}$, Pierre Avril ${ }^{10}$, Jean Christophe Pagès ${ }^{2,8}$ and Gonzague de Pinieux ${ }^{1,8,10}$

${ }^{1}$ Department of Pathology, University Hospital of Tours, Avenue de la République, Chambray-les-tours, France; ${ }^{2}$ Molecular Biology Platforms, University Hospital of Tours, Avenue de la République, Chambray-lestours, France; ${ }^{3}$ Department of Pathology, Hôpital Cochin, Assistance Publique-Hôpitaux de Paris, Université Paris Descartes, Sorbonne Paris Cité, Paris, France; ${ }^{4}$ Department of Pathology, University Hospital of Marseille, Marseille, France; ${ }^{5}$ Department of Pathology, University Hospital of Lille, avenue Oscar Lambret, Lille, France; ${ }^{6}$ Department of Pathology, University Hospital of Toulouse, Toulouse, France; ${ }^{7}$ Department of Pathology, University Hospital of Nancy, Nancy, France; ${ }^{8}$ Faculté de Médecine de Tours, Université François Rabelais, Tours, France; ${ }^{9}$ Department of Orthopaedic Surgery, University Hospital of Tours, Avenue de la République, Chambray-les-tours, France and ${ }^{10}$ INSERM UMR-957, Physiopathologie de la Résorption Osseuse et Thérapies des Tumeurs Primitives, Laboratory, Nantes, France

Behjati et al recently described recurrent mutations of H3F3 genes in giant cell tumors of the bone and chondroblastomas. Both these entities belong to the spectrum of giant cell-rich bone lesions, often presenting a diagnostic challenge for the pathologist. Our aim was to investigate the value of searching for H3F3 mutations in the diagnosis of giant cell tumors of the bone and giant cell-rich chondroblastomas. Two hundred eighty-one bone lesion samples, including $\mathbf{1 7 0}$ giant cell tumors of the bone, $\mathbf{2 6}$ chondroblastomas and 85 other giant cellrich and/or epiphyseal tumors, were analyzed. Mutation status was determined using first high resolution melting screening and then mutation profiling pyrosequencing. Mutational status was compared with clinical data and, for giant cell tumors of the bone, with p63 immunostaining status. As histone methylation changes have been reported in association with $\mathrm{H} 3 \mathrm{~F} 3$ mutations, the methylation status of lysine 37 was investigated. H3F3A and $H 3 F 3 B$ were found in $85 \%$ of giant cell tumors of the bone and $88 \%$ of chondroblastomas. In addition to the major G35W mutation, we found two rare H3F3A mutations: one G35R and one G35V. Among the other tumors studied, we only found $H 3 F 3 A$ gene mutations in two cases of 'dedifferentiated chondrosarcoma mimicking giant cell tumor of the bone'. A H3F3B mutation was also observed in one case of dedifferentiated chondroblastoma. P63 expression in giant cell tumors of the bone seems to be associated with H3F3 gene mutations $(P=0.004)$. H3F3 mutations did not correlate with clinical data, outcome or methylation changes in Lysin 37. In conclusion, H3F3 mutations are sensitive and specific markers of giant cell tumors of the bone and chondroblastomas. High resolution melting and pyrosequencing procedures are high-performance tools in this context. Determination of H3F3 mutation will allow reclassification of some entities belonging to the spectrum of giant cell-rich lesions. Modern Pathology (2017) 30, 393-406; doi:10.1038/modpathol.2016.212; published online 6 January 2017

Correspondence: Professor G de Pinieux, Department of Pathology, University Hospital of Tours, Avenue de la République, Chambray-les-tours 37170, France.

E-mail: gonzague.dubouexic@univ-tours.fr

Received 7 July 2016; revised 24 October 2016; accepted 25 October 2016; published online 6 January 2017
Giant cell tumors of the bone and chondroblastomas are tumors of intermediate behavior, ${ }^{1}$ which are locally aggressive, with minimal metastatic potential and occur in young adults. The most common location of these tumors is the epiphysis of long 
bones. The tumor may invade the articular compartment leading to local joint destruction.

In most cases, treatment of these lesions is based on conservative surgery by bone curettage, resulting in a local tumor recurrence rate in $10-20 \%$ of cases. $^{2,3}$ The use of bisphosphonates ${ }^{4}$ and antiRANKL monoclonal antibodies ${ }^{5}$ was proposed recently as adjuvant therapy in giant cell tumors of the bone. Pulmonary tumor implants are described in about $3 \%$ and $1 \%$ of cases of giant cell tumors of the bone ${ }^{6}$ and chondroblastomas, ${ }^{7}$ respectively. Rare malignant forms of giant cell tumors of the bone ${ }^{8}$ and even rarer malignant forms of chondroblastomas with a sarcomatous component have been reported.

Diagnosis of both these lesions on histological examination is mainly based on the cytological features of the mononuclear tumor cells. Immunohistochemical markers, including p63 (ref. 9) for giant cell tumors of the bone, and S100 protein, Sox9 and DOG1 for chondroblastomas, may be helpful in some cases.

Both these entities belong to the especially challenging diagnosis spectrum of giant cell-rich bone lesions, along with many other entities with various clinical outcomes, such as aneurysmal bone cysts, giant cell lesions of small bones and central giant cell granulomas of the jawbones. The advent of core needle biopsy in bone pathology requires the development of new markers to provide a reliable pathological diagnosis.

Recurrent mutations of $H 3 F 3 A$ and $H 3 F 3 B$ genes, encoding H3.3 histone, were recently described in $92 \%$ of giant cell tumors of the bone and $95 \%$ of chondroblastomas. ${ }^{10}$

The main purpose of the study presented here was to investigate $H 3 F 3$ mutation as a diagnostic tool for giant cell tumors of the bone and chondroblastomas in standard practice. As both mutations are each restricted to a single base pair, we chose to assess two current targeted mutation analysis techniques: high resolution melting and pyrosequencing. These two molecular analyses were validated in comparison with Sanger sequencing. We therefore analyzed 281 samples of bone tumors by high resolution melting, including giant cell tumors of the bone and chondroblastomas, and bone tumors included in their differential diagnosis, especially giant cell-rich bone lesions. When a distinct melting curve compared with the wild-type allele was observed, pyrosequencing was performed to characterize the mutation.

H3F3 mutational status was compared with clinical data for giant cell tumors of the bone and chondroblastomas, and for p63 immunostaining status for giant cell tumors of the bone.

As recurrent $I D H$ mutations have recently been reported in giant cell tumors of the bone, ${ }^{11} \mathrm{IDH}$ mutational status was determined in this setting at the same time.

H3F3 methylation changes have been reported as a major determinant of the oncogenic properties of
H3F3 mutations in pediatric glioblastoma. ${ }^{12}$ As there is a strong association between methylation changes and mutations of the $\mathrm{H} 3 \mathrm{~F} 3$ gene, these changes are investigated in current practice by immunohistochemistry and serve as diagnostic markers in current practice in pediatric neuropathology. In this study, we investigated the methylation status of $H 3 F 3$ lysine 37 of giant cell tumors of the bone and chondroblastomas as a diagnostic marker.

\section{Materials and methods}

\section{Genetic Study}

Selection of samples. The design of this retrospective study was in agreement with the requirements for the use of biological material in research proposed by our institutional ethics guidelines.

The tumor samples analyzed in this study were giant cell tumors of the bone, chondroblastomas, giant cell-rich lesions and clear cell chondrosarcomas diagnosed in the French Bone Pathology Group network between 2005 and 2015.

We analyzed 170 samples of giant cell tumors of the bone, subdivided into 51 frozen samples and 119 formalin-fixed paraffin-embedded samples. These 170 samples were taken from 133 patients (96 patients with one sample and 37 patients with two samples). They consisted of 35 needle biopsy samples, 30 open biopsy samples and 105 surgical specimens (subdivided into 76 surgical curettages and 29 surgical excisions). These 170 cases of giant cell tumors of the bone included 7 tumors with pulmonary tumor implants, 11 tumors after denosumab treatment and 2 malignant giant cell tumors of the bone.

Twenty-six samples of chondroblastoma, subdivided into 9 frozen samples and 17 formalin-fixed paraffin-embedded samples, were analyzed. These 26 samples originated from 25 patients. They consisted of 3 open biopsy samples and 23 surgical excision specimens. There was one malignant case among these 26 chondroblastomas, consisting of the juxtaposition of morphologically typical chondroblastoma areas with high-grade osteosarcomatous areas.

The third group of samples studied consisted of various lesions that could be included in the clinicopathological differential diagnosis of giant cell tumor of the bone and chondroblastomas, and included 60 samples of giant cell-rich bone lesions (41 aneurysmal bone cysts; 6 central giant cell granulomas of the jaw; 3 giant cell lesions of small bones; 2 brown tumors associated with hyperparathyroidism; 3 dedifferentiated chondrosarcomas mimicking giant cell tumor of the bone (lesion characterized by the combination of a low grade hyaline cartilaginous component and a morphologically identical to conventional giant cell tumors of the bone component); 1 chondrosarcoma with 
chondroblastoma-like features; 1 giant cell-rich highgrade osteosarcoma and 3 epiphyseal not otherwise specified giant cell-rich tumors), 19 tenosynovial giant cell tumors, which may subsequently invade bone, and a subgroup of six clear cell chondrosarcomas, a third typically epiphyseal bone tumor that may cytologically mimick chondroblastoma. An additional control group of six conventional dedifferentiated chondrosarcomas was also assessed.

Of these 85 samples, 62 were frozen tissues and 23 were formalin-fixed paraffin samples (9 aneurysmal bone cysts; 3 giant cell lesions of small bones; 3 dedifferentiated chondrosarcomas mimicking giant cell tumor of the bone, 1 chondrosarcoma with chondroblastoma-like features; 1 giant cell-rich highgrade osteosarcoma and 6 clear cell chondrosarcomas).

Hematoxylin, eosin and saffron-stained (HES) slides were reviewed independently by two pathologists (GdP and TK) blinded to the molecular studies. Tumor samples were decalcified in either formic acid or hydrochloric acid.

Clinical and pathological data. For giant cell tumors of the bone and chondroblastomas patients, the following clinical data were collected: age, sex, tumor location, treatment, and occurrence of relapse or pulmonary implants.

On microscopic examination, the presence of tumor necrosis and changed (fibrous changes, aneurysmal changes, collections of foamy macrophages and reactive osteogenesis) tumor areas were noted if $>50 \%$ of the tumor was involved. Tumors were classified as 'highly mitotic' if microscopic examination revealed more than one mitotic figure per highpower field $(\times 40)$.

Immunohistochemistry. P63 status was determined in cases of giant cell tumors of the bone for which material from the FFPE block used for the molecular H3F3 study was still available. Only representative blocks with a conserved area of giant cell tumors of the bone were selected. Immunohistochemical procedures were performed on paraffin sections according to the manufacturer's instructions on a BenchMark XT platform. Immunostaining was performed with an anti-p63 antibody (Dako, clone 4A4, dilution 1:100) after an antigen retrieval procedure (Ultraview universal DAB kit; ref 760-500 Ventana Roche).

In accordance with a previous study, ${ }^{9}$ p63 positivity was recorded when $>1 \%$ of the mononuclear tumor cells showed nuclear expression and strong positivity was recorded when $>50 \%$ of the mononuclear cells showed nuclear staining.

\section{Molecular studies}

DNA extraction. Genomic DNA (gDNA) was isolated from tissue samples using a Maxwell ${ }^{\circledR} 16$ Instrument (Promega) with the Maxwell ${ }^{\circledR} 16$ FFPE Plus LEV DNA purification kit (Promega) according to the manufacturer's instructions.
High resolution melting. High resolution melting screening for $H 3 F 3 A$, H3F3B, IDH1 and IDH2 was performed on a LightCycler ${ }^{\circledR} 480$ II (Roche) using the LightCycler ${ }^{\circledR} 480$ High Resolution Melting Master Kit (Roche). Each reaction contained $10 \mu \mathrm{l}$ of $2 \mathrm{X}$ Master Mix, $2.4 \mu \mathrm{l}$ of $25 \mathrm{mM} \mathrm{MgCl}_{2}, 3.6 \mu \mathrm{l}$ of $\mathrm{H}_{2} \mathrm{O}, 1 \mu \mathrm{l}$ of each $10 \mu \mathrm{M}$ primer and $2 \mu \mathrm{l}$ of DNA (30 ng) in a total volume of $20 \mu \mathrm{l}$. The high resolution melting primers (Invitrogen) are given in Supplementary Table S1. The final product sizes for H3F3A, H3F3B, IDH1 and IDH2 were 137, 60, 56 and $87 \mathrm{bp}$, respectively. The cycling conditions were $95{ }^{\circ} \mathrm{C}$ for $5 \mathrm{~min}$, followed by 50 cycles at $95^{\circ} \mathrm{C}$ for $15 \mathrm{~s}, 55^{\circ} \mathrm{C}$ for $15 \mathrm{~s}$ and $72^{\circ} \mathrm{C}$ for $20 \mathrm{~s}$. The melting conditions included a cycle at $95^{\circ}$ C for $1 \mathrm{~min}, 40^{\circ} \mathrm{C}$ for $1 \mathrm{~min}$ and $65^{\circ} \mathrm{C}$ for $2 \mathrm{~s}$, followed by an increase in temperature from 65 to $95^{\circ} \mathrm{C}$ at $1^{\circ} \mathrm{C} / \mathrm{s}$. All samples were tested in duplicate. Data were analyzed with LightCycler 480 SW1.5 software. The normalized melting curves were established for each sample and samples were compared with sample controls in a deduced difference plot. Significant deviations from the horizontal line, relative to the wild-type controls curve, were indicative of sequence changes within the amplicon analyzed. The samples with distinct melting curves, compared with the wildtype allele, were recorded as potentially positive for a mutation and pyrosequencing was performed. Representative curves are shown in Figure 1.

Pyrosequencing. PCR was performed using the PyroMark PCR Kit (Qiagen): 30 ng of DNA was added to $20 \mu \mathrm{l}$ of a reaction mix containing $2.5 \mu \mathrm{l}$ of CoralLoad 10X, $12.5 \mu \mathrm{l}$ of master mix and $10 \mathrm{pmol}$ of each primer. The PCR conditions were: $15 \mathrm{~min}$ at $95^{\circ} \mathrm{C}$ followed by $20 \mathrm{~s}$ at $94^{\circ} \mathrm{C}, 30 \mathrm{~s}$ at $53^{\circ} \mathrm{C}$ and $20 \mathrm{~s}$ at $72{ }^{\circ} \mathrm{C}$ for 42 cycles, and $5 \mathrm{~min}$ at $72^{\circ} \mathrm{C}$. Then $10 \mu \mathrm{l}$ of PCR product were added to a DNA immobilization mix containing $1 \mu \mathrm{l}$ of streptavidin beads (GE Healthcare), $40 \mu \mathrm{l}$ of PyroMark binding buffer (Qiagen) and $29 \mu \mathrm{l}$ of $\mathrm{H}_{2} \mathrm{O}$ on a 24-well plate. After sealing, the plate was agitated for $10 \mathrm{~min}$ at 1400 r.p.m. on a plate-mixer. Using a PyroMark workstation, single-stranded DNA was added to a PyroMark Q24 plate in $25 \mu \mathrm{l}$ of sequencing primer (8 pmol) in an annealing buffer. After $2 \mathrm{~min}$ at $80^{\circ} \mathrm{C}$, the plate was kept at room temperature for $20 \mathrm{~min}$ before processing the pyrosequencing reaction.

Pyrosequencing was performed on a PyroMark Q24 (Qiagen). The sequences analyzed were 5'-GA DGGGTGARGAAACCTC-3' or 5'-GAGKGGTGARGA AACCTC-3' and 5'-GCRGGGTGAWGAAG-3'. The nucleotide dispensation order was 5'-TGCATGGTG TGAGACT-3' and 5'-AGTCGGAGTCGATGA-3' for $H 3 F 3 A$ and $H 3 F 3 B$, respectively (Supplementary Table S1). The results were analyzed using PyroMark sw 2.0.6 software (Qiagen) and representative results are shown in Figures 2 and 3.

PCR amplification and DNA sequencing. For the PCR reaction, $2 \mu \mathrm{l}$ of $10 \mathrm{X}$ polymerase buffer, $1.2 \mu \mathrm{l}$ of $25 \mathrm{mM}$ of $\mathrm{MgCl}_{2}, 0.4 \mu \mathrm{l}$ of $10 \mathrm{mM} \mathrm{dNTP}, 1 \mu \mathrm{l}$ of each 


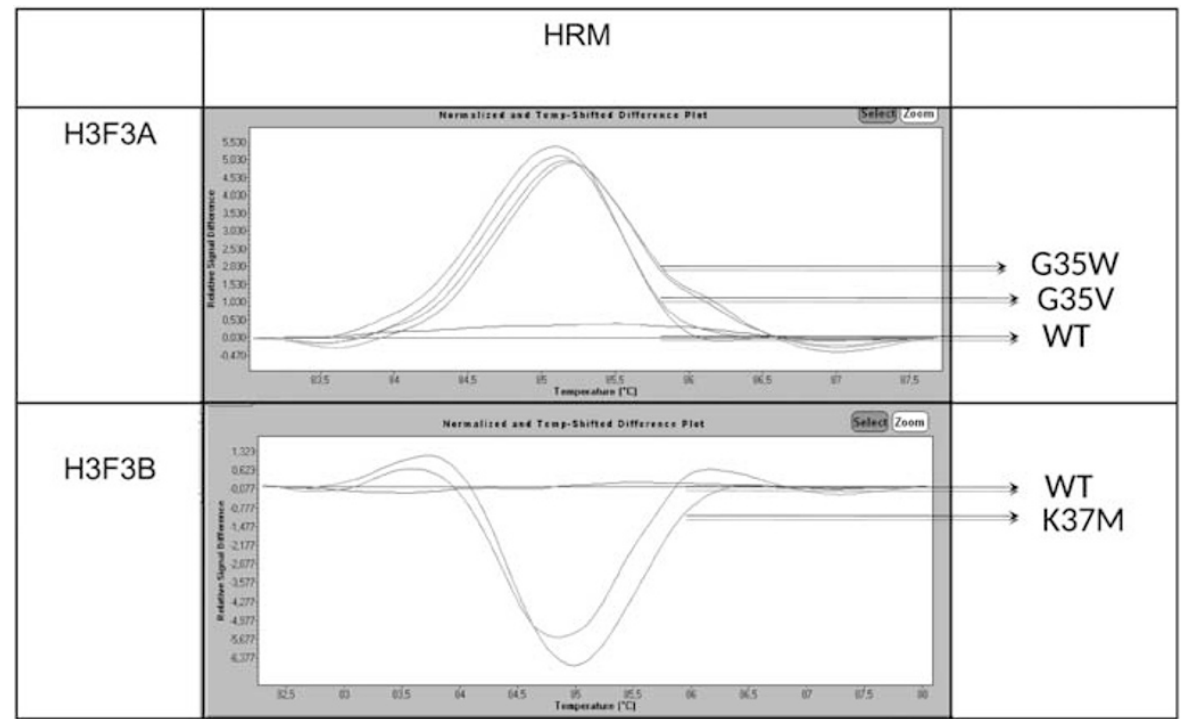

Figure $1 H 3 F 3$ genes mutations investigated by high resolution melting. WT, wild type.

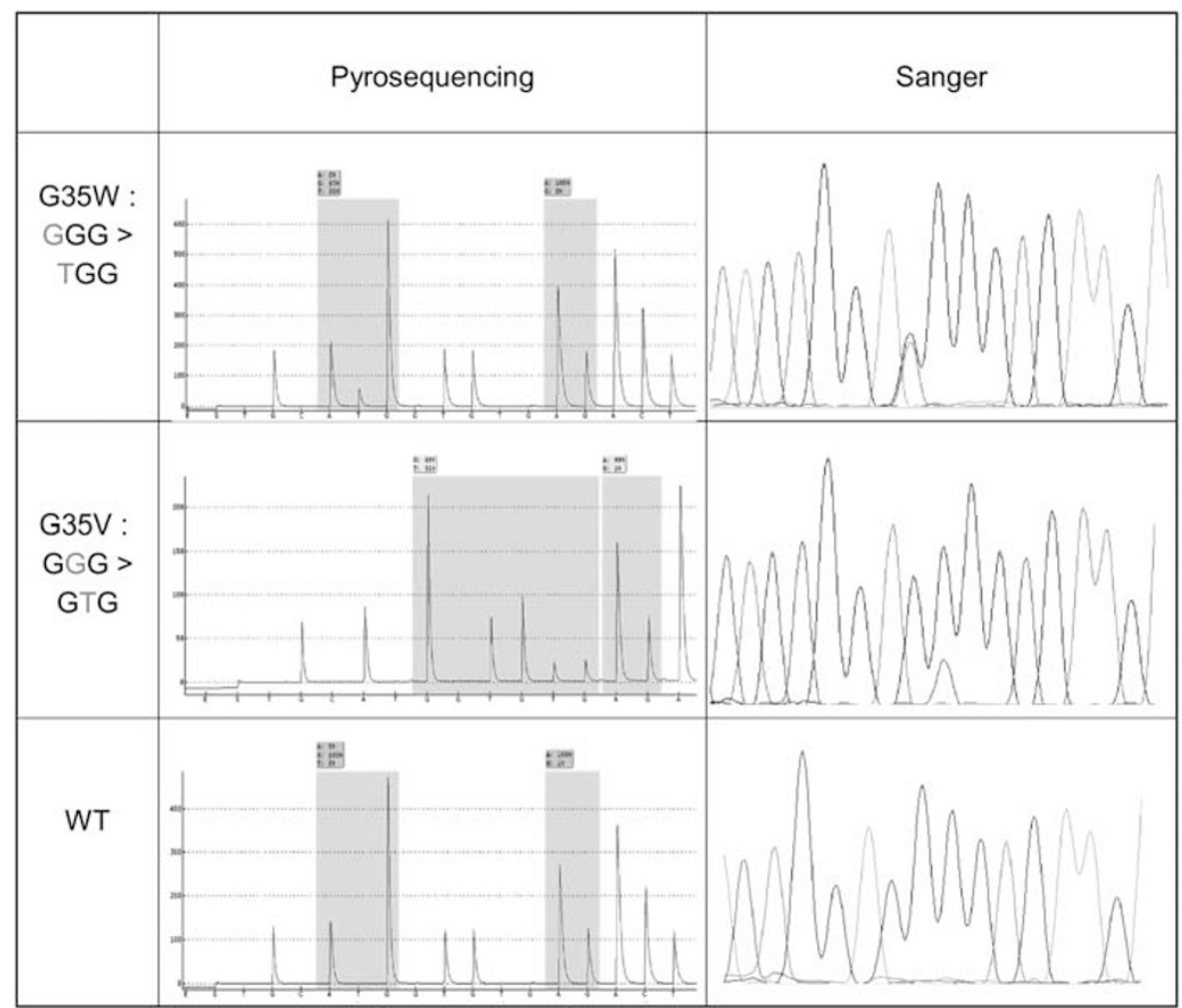

Figure $2 H 3 F 3 A$ gene mutations investigated by pyrosequencing and Sanger methods. WT, wild type.

$10 \mu \mathrm{M}$ primer (Supplementary Table S1), 1 unit of AmpliTaq Gold ${ }^{\circledR}$ DNA Polymerase (Applied Biosystems), $12 \mu \mathrm{l}$ of $\mathrm{H}_{2} \mathrm{O}$ and $80 \mathrm{ng}$ of gDNA were mixed in a final volume of $20 \mu \mathrm{l}$. The PCR conditions were: $95{ }^{\circ} \mathrm{C}$ for $8 \mathrm{~min}$ followed by 35 cycles at $94^{\circ} \mathrm{C}$ for $45 \mathrm{~s}, 55^{\circ} \mathrm{C}$ for $45 \mathrm{~s}$ and $72{ }^{\circ} \mathrm{C}$ for $1 \mathrm{~min}$, and $72^{\circ} \mathrm{C}$ for 7 min.
PCR products were purified with ExoI and Fast-AP (Fermentas) according to the manufacturer's instructions. The sequencing reaction was performed using the Big Dye terminator V3.1 cycle sequencing kit (Applied Biosystems) according to the manufacturer's protocol and using primers at $2 \mu \mathrm{M}$. The sequencing products were purified using the BigDye 


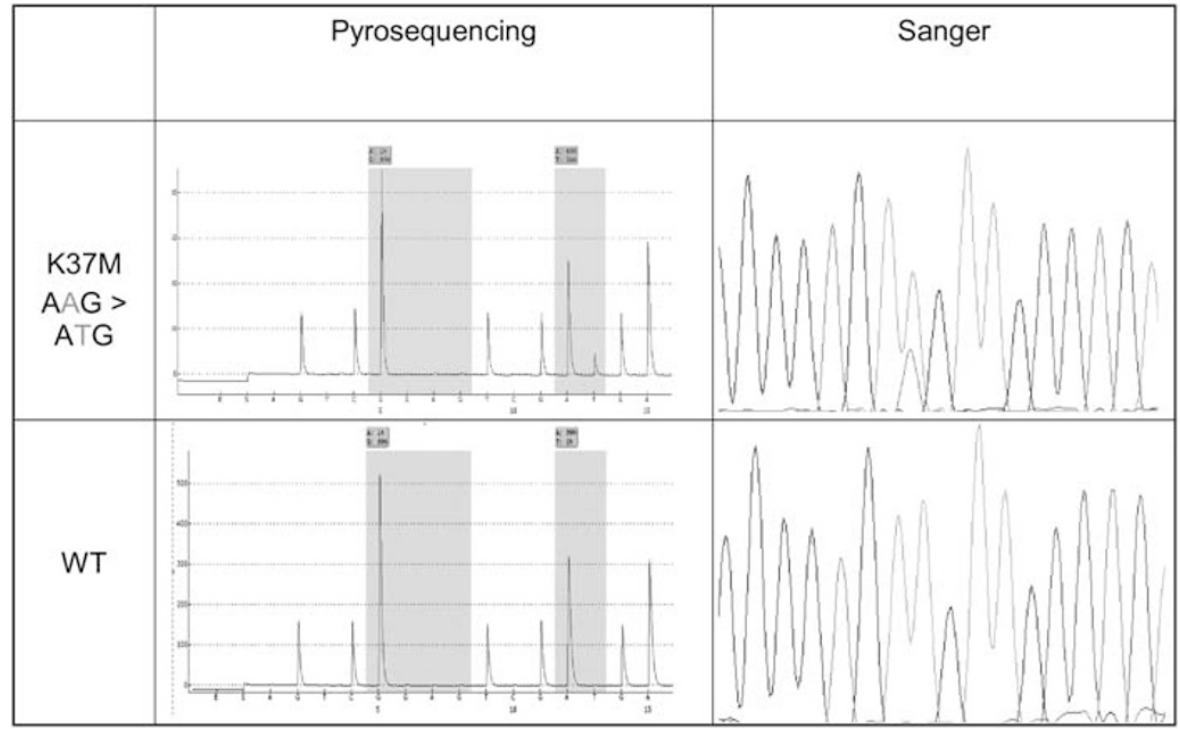

Figure $3 H 3 F 3 B$ gene mutation investigated by pyrosequencing and Sanger methods. WT, wild type.

Xterminator purification kit (Applied Biosystems) before running on a 3130 Genetic Analyzer (Applied Biosystems). The sequencing data were analyzed using the Sequencing Analysis software (Applied Biosystems). Representative results are shown in Figures 2 and 3.

Molecular technique management. The first 28 samples (16 giant cell tumors of the bone, 8 chondroblastomas and 4 central giant cell granulomas) were analyzed using Sanger sequencing, pyrosequencing and high resolution melting to validate each technique. Next, all samples were screened with high resolution melting, and pyrosequencing was performed for all samples in which an abnormal melting curve was identified.

In this study, we used the standard mutation nomenclature, ${ }^{13}$ which differs from some other reports, the G35W H3F3A mutation being previously reported as the G34W mutation.

\section{Methylation Study}

Selection of samples. Our aim was to investigate the impact of $H 3 F 3$ gene mutation on the K37 lysine located near the mutated amino-acid residues of the H3 histone. As histone extraction of normal bone tissue is not a feasible process, we used other benign enriched giant cell neoplasms as controls. From the previously studied samples, we selected frozen samples of 21 giant cell tumors of the bone, 6 chondroblastomas, 19 tenosynovial giant cell tumors, 11 aneurysmal bone cysts and 1 central giant cell granuloma of the jawbone.

Histone extraction. One to $2 \mathrm{~mm}^{3}$ of $-80^{\circ} \mathrm{C}$ frozen tumor samples were used. Tumor tissues were homogenized in $1 \mathrm{ml}$ of TEB Buffer $(0.5 \%$ Triton X 100, $2 \mathrm{mM}$ PMSF, $0.02 \mathrm{NaN} 3$ in PBS) at $200 \mathrm{mg} / \mathrm{ml}$ and were crushed using a Tissulyser LT (Qiagen). Homogenates were centrifuged at 10000 r.p.m. for $1 \mathrm{~min}$ at $4{ }^{\circ} \mathrm{C}$ and supernatants were removed. Pellets were resuspended in $600 \mu \mathrm{l}$ extraction buffer $(0.5 \mathrm{~N}$ HCL, $10 \%$ glycerol) and incubated for 30 min on ice. The mixtures were centrifuged at 12000 r.p.m. for 5 min at $4{ }^{\circ} \mathrm{C}$, and supernatants were removed and mixed with $1400 \mu \mathrm{l}$ acetone and incubated overnight at $-20^{\circ} \mathrm{C}$. Samples were centrifuged at 12000 r.p.m. for $5 \mathrm{~min}$, and the resulting pellets were air-dried. Isolated histones were dissolved in distilled water, and quantified using Nanodrop Lite.

Quantification of global methylation by Elisa test. An Elisa test was performed using an ab115081Histone H3 (pan-methylK36) Colorimetric Quantification Kit (Abcam, Cambridge, UK) according to the manufacturer's instructions. An antibody cocktail was designed to detect mono, di- and trimethylation on the lysine 37 residues of all H3 histones.

Western blotting. We then specifically investigated H3K37 trimethylation status. Analysis was performed on only 23 samples because tumor material was lacking for some of the tumors. An H3-3K36 me3 antibody (Abcam, AB9050) was used according to the manufacturer's instructions: $5 \mu \mathrm{g}$ of histone extract were spotted per pit. Staining intensity of methylated histone was compared with GAPDH using Image J software.

Statistical analysis. Continuous data were described as medians with extremities and categorical data as numbers and percentages. Proportional analysis was assessed using the two-tailed Fisher's exact test. Continuous variables were compared 
using the non-parametric Mann-Whitney $U$-test. Methylation rates were compared between wildtype tumors and mutated tumors in both the giant cell tumors of the bone and chondroblastomas populations using a Student $t$-test.

Statistical tests were performed using XL-Stat-Life software (Addinsoft, Paris, France). $P$-values $<0.05$ were considered significant.

\section{Results}

\section{Population Characteristics}

All clinical data were available for 125 patients with a diagnosis of giant cell tumors of the bone. Clinical data were lacking for two patients, tumor location for two patients and follow-up and treatment for four patients. Clinical information was available for all patients with chondroblastomas except for location, treatment and follow-up data for two patients. The data are summarized in Table 1.

\section{Validation of Molecular Analyses and Diagnostic Strategy}

In 27 of the first 28 cases tested, Sanger sequencing and pyrosequencing showed consistent results for H3F $3 A$ and $H 3 F 3 B$ mutation status (Table 2). In one case of chondroblastomas exhibiting areas of ischemic necrosis, pyrosequencing revealed a small percentage of mutated $H 3 F 3 B(12 \%)$ not detected by Sanger sequencing. High resolution melting analysis and Sanger sequencing were concordant in 24 cases (Table 2). Ambiguous profiles for H3F3A were found in three cases, for which pyrosequencing revealed two wild-type genotypes, and a low frequency of H3F3A mutation was detected in a patient with giant cell tumors of the bone. Only one patient had an ambiguous high resolution melting profile for $H 3 F 3 B$, this case being the pyrosequencing-positive/Sanger-negative sample discussed above. The high sensitivity of high resolution melting and the high level of consistency between Sanger sequencing and pyrosequencing supported our diagnostic method based on high resolution melting screening followed by confirmation by pyrosequencing.

\section{H3F3 Gene Mutation in Giant Cell Tumors of the Bone}

High resolution melting screening for $H 3 F 3 A$ status provided detection of 120 mutations, which were all confirmed by pyrosequencing (1 G35V and 119 G35W). For the others, 16 samples were shown to have a wild-type genotype. Pyrosequencing performed on ambiguous and uninterpretable profiles $(n=34)$ revealed 1 G35R and 8 G35W mutations and 10 wild-type genotypes. Only 15 samples were definitively uninterpretable (3 core needle biopsies, 3 surgical biopsies and 9 surgical specimens). Finally, our study found H3F3 gene mutations in
Table 1 Population characteristics

\begin{tabular}{|c|c|c|}
\hline & $\begin{array}{l}\text { Giant cell tumors } \\
\text { of the bone }\end{array}$ & $\begin{array}{l}\text { Chondro- } \\
\text { blastomas }\end{array}$ \\
\hline Patients/samples & $133 / 170$ & $25 / 26$ \\
\hline Mean age at diagnosis (years) & $34(11-80)$ & $21.5(13-50)$ \\
\hline Sex ratio & $0.79(58 \mathrm{M} / 73 \mathrm{~W})$ & $1.8(16 \mathrm{M} / 9 \mathrm{~W})$ \\
\hline \multicolumn{3}{|l|}{ Locations } \\
\hline Distal femoral epiphysis & 33 cases $(26 \%)$ & 6 cases $(26 \%)$ \\
\hline Proximal tibial epiphysis & 23 cases $(18 \%)$ & 6 cases $(26 \%)$ \\
\hline Local recurrence & 18 cases $(14 \%)$ & 2 cases $(9 \%)$ \\
\hline $\begin{array}{l}\text { Malignant form with } \\
\text { sarcomatous component }\end{array}$ & 2 cases $(2 \%)$ & 1 case $(4 \%)$ \\
\hline Pulmonary implants & 6 cases $(5 \%)$ & 0 \\
\hline Denosumab treatment & 11 cases $(9 \%)$ & 0 \\
\hline Curettage & 82 cases $(65 \%)$ & 20 cases $(87 \%)$ \\
\hline Resection & 45 cases $(35 \%)$ & 3 cases $(13 \%)$ \\
\hline
\end{tabular}

Table 2 Molecular analysis

\begin{tabular}{llrcc}
\hline Gene & Mutation status & HRM & PyroSeq. & Sanger \\
\hline H3F3A & Mutations & 12 & 12 G35W & $12 \mathrm{G} 35 \mathrm{~W}$ \\
& & & $2 \mathrm{G} 35 \mathrm{~V}$ & $2 \mathrm{G} 35 \mathrm{~V}$ \\
& Ambiguous & 3 & 0 & 0 \\
H3F3B & Wild-type & 13 & 14 & 14 \\
& Mutations & 5 & $6 \mathrm{~K} 37 \mathrm{M}$ & $5 \mathrm{~K} 37 \mathrm{M}$ \\
& Ambiguous & 1 & 0 & 0 \\
& Wild-type & 22 & 22 & 23 \\
\hline
\end{tabular}

Abbreviation: PyroSeq., pyrosequencing.

105 of the 124 giant cell tumor of the bone patients with interpretable samples (85\%). Mutation status per patient are summarized in Figure 4. Mutation rates of the interpretable samples of core needle biopsies, surgical biopsies or surgical specimens were $90 \%, 85 \%$ and $74 \%$ respectively. Concerning patients for which two samples were analyzed and interpretable $(n=31)$, mutation status of the biopsy and the surgical specimen matched in all cases, except for patients treated with denosumab.

In order to increase the sensitivity of our analysis, new core needle sampling was performed on the more preserved areas of four cases of wild-type tumors exhibiting major changes. This detected one additional $H 3 F 3 A$ mutation.

The uninterpretable samples corresponded to decalcified formalin-fixed paraffin samples $(n=11)$ or to FFPE giant cell tumors of the bone after denosumab treatment $(n=4)$.

An initial pretreatment biopsy sample was available for 7 of the 11 samples of giant cell tumors of the bone treated by monoclonal anti-rank ligand antibody. Study of these initial samples revealed H3F3 mutations in two of the three tumors exhibiting a wild-type genotype after treatment.

One G35V was detected in a tumor located at the proximal tibia epiphysis in a 26-year-old patient. 


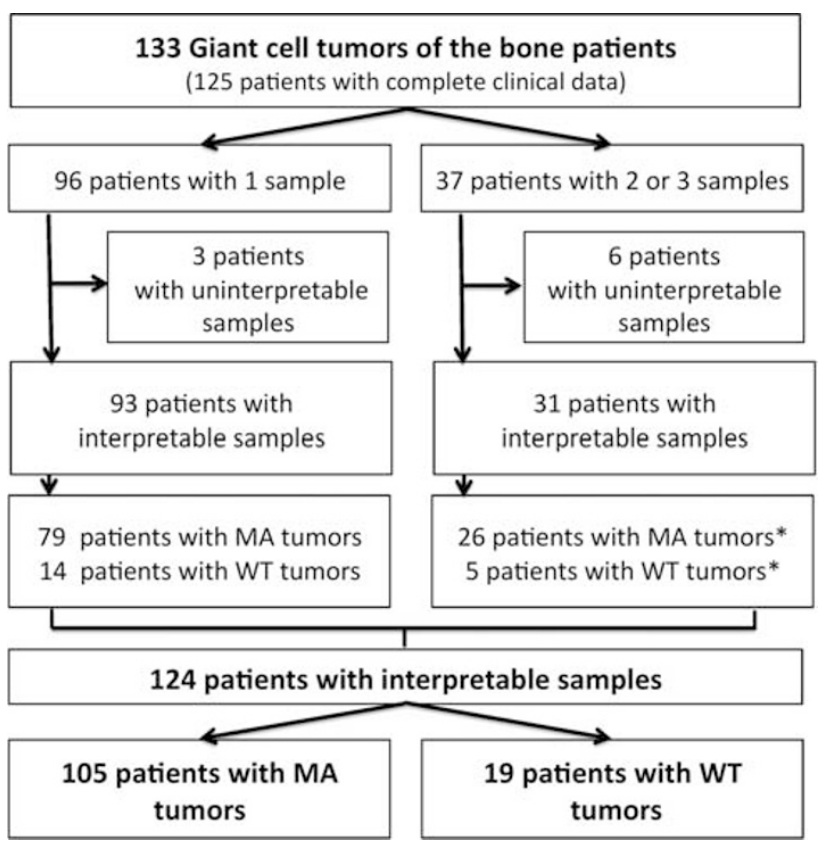

Figure 4 Flow chart of the giant cell tumors of the bone patients according to the mutation status. MA, mutation of $H 3 F 3 A$; MB, mutation of $H 3 F 3 B$; WT, wild-type. *Theses patients corresponding to 22 patients with MA giant cell tumors of the bone on both samples, 1 patient with MA giant cell tumors of the bone on three samples, 4 patients with WT giant cell tumors of the bone on both samples, 2 patients with MA giant cell tumors of the bone on one sample and WT giant cell tumors of the bone on one sample (patients treated with Denosumab), 2 patients with one interpretable sample ( $1 \mathrm{WT}$ and $1 \mathrm{MA}$ ).

Surgery was successful with knee arthrodesis and the patient had no recurrence. The giant cell tumor of the bone with G35R mutation showed one local tumor recurrence after 10 months. The patient was treated surgically and no other recurrence occurred during additional follow-up of 10 months.

High resolution melting analysis for $H 3 F 3 B$ did not allow detection of any mutation in the giant cell tumor of the bone samples. We obtained 18 unambiguous profiles and 6 samples could not be interpreted. Pyrosequencing did not reveal any further mutation.

The results for $\mathrm{H} 3 \mathrm{~F} 3$ gene mutation status in giant cell tumors of the bone are summarized in Table 3 and details of the analysis strategy are provided in Figure 5.

\section{H3F3 Gene Mutations in Chondroblastomas}

Eighteen $H 3 F 3 B$ gene mutations were detected by high resolution melting screening for chondroblastomas patients. Pyrosequencing confirmed the presence of mutations for all 18 patients, and characterized these changes as $\mathrm{K} 37 \mathrm{M}$ mutations. It is of note that the two ambiguous high resolution melting profiles corresponded to K37M mutations. For one of these samples, pyrosequencing detected a small percentage of mutation (12\%), whereas Sanger sequencing failed to reveal this mutation.

Interestingly, we identified a K37M H3F3A gene mutation in a metaphyseal-epiphyseal bone tumor consisting of the sudden transition between typical areas of chondroblastoma and high-grade osteosarcoma, classified as dedifferentiated chondroblastoma. The morphologic features of this extremely rare tumor are shown in Figure 6. No other H3F3A mutation was detected in the group of chondroblastomas.

Finally, mutation of $\mathrm{H} 3 \mathrm{~F} 3$ was detected in 21 of the 24 patients with interpretable samples (88\%).

The results for $\mathrm{H} 3 \mathrm{~F} 3$ gene mutation status in chondroblastomas are summarized in Table 3 and details of the analysis strategy are provided in Figure 5.

\section{H3F3 Gene Mutations in Giant Cell-Rich Lesions of the Bone and Clear Cell Chondrosarcomas}

H3F3 gene mutations were absent from central giant cell granulomas, giant cell lesions of small bones, tenosynovial giant cell tumors, brown tumors and giant cell-rich osteosarcomas. Samples of clear cell chondrosarcomas also exhibited no mutations.

We detected a G35W mutation in the H3F3A gene in two of the three cases of dedifferentiated chondrosarcoma mimicking giant cell tumor of the bone, the third being uninterpretable. Core sampling was performed on giant cell tumor of the bone and cartilage areas on one of the mutated samples. H3F3 mutation was found in both these areas. Microscopic features of this tumor are shown in Figure 7.

In the two cases of epiphyseal not otherwise specified giant cell-rich tumors exhibiting ambiguous cytological features between giant cell tumors of the bone and chondroblastomas, a H3F3A mutation was found in one case, suggesting a diagnosis of giant cell tumor of the bone. The second tumor exhibited a wild-type genotype, and remained as 'unclassified epiphyseal giant cell-rich tumor of bone with both chondroblastoma and giant cell tumor features'.

H3F3 mutations were absent in the control group of six cases of conventional central dedifferentiated chondrosarcoma studied.

The results for $H 3 F 3$ gene mutation status in the clinico-pathological mimics of giant cell tumors of the bone and chondroblastomas are summarized in Table 3.

\section{Comparative Study between H3F3 Mutation Status, Clinical and Histopathological Features in Giant Cell Tumors of the Bone and Chondroblastomas}

Clinical data from patients with and without $H 3 F 3$ mutations are summarized in Tables 4 and 5.

We did not find any statistically significant difference in the clinical characteristics of the giant cell 
Table 3 Tumor mutations per status

\begin{tabular}{|c|c|c|c|}
\hline Initial diagnosis & Number of samples/patients & $\begin{array}{l}\text { H3F3A mutations } \\
\text { (number of patients) }\end{array}$ & $\begin{array}{l}\text { H3F3B mutations } \\
\text { (number of patients) }\end{array}$ \\
\hline $\begin{array}{l}\text { Giant cell tumors of the bone without implants or } \\
\text { malignant form }\end{array}$ & $150 / 121$ & $\begin{array}{l}95 \mathrm{G} 35 \mathrm{~W}, 1 \mathrm{G} 35 \mathrm{~V}, 1 \\
\text { G35R }\end{array}$ & 0 \\
\hline Giant cell tumors of the bone with pulmonary implants & $7 / 6$ & $3 \mathrm{G} 35 \mathrm{~W}$ & 0 \\
\hline Malignant giant cell tumors of the bone & $2 / 2$ & 2 G35W & 0 \\
\hline Giant cell tumors of the bone after denosumab & $\begin{array}{l}\text { 11/11 (including } 4 \text { patients } \\
\text { without prior biopsy) }\end{array}$ & 4 G35W & 0 \\
\hline Chondroblastomas without malignant form & $25 / 24$ & 0 & $20 \mathrm{~K} 37 \mathrm{M}$ \\
\hline Dedifferentiated chondroblastoma & $1 / 1$ & $1 \mathrm{~K} 37 \mathrm{M}$ & 0 \\
\hline Aneurysmal bone cysts & $41 / 39$ & 0 & 0 \\
\hline Central giant cell granulomas of the jaw & $6 / 6$ & 0 & 0 \\
\hline Giant cell lesions of small bones & $3 / 3$ & 0 & 0 \\
\hline Tenosynovial giant cell tumors & 19/19 & 0 & 0 \\
\hline Brown tumor & $2 / 2$ & 0 & 0 \\
\hline Clear cell chondrosarcomas & $6 / 6$ & 0 & 0 \\
\hline $\begin{array}{l}\text { Dedifferentiated chondrosarcoma mimicking giant cell } \\
\text { tumors of the bone }\end{array}$ & $3 / 3$ & 2 G35W & 0 \\
\hline Chondrosarcoma with chondroblastoma features & $1 / 1$ & 0 & 0 \\
\hline Giant cell-rich osteosarcoma & $1 / 1$ & 0 & 0 \\
\hline $\begin{array}{l}\text { Epiphyseal giant cell-rich lesion not otherwise } \\
\text { specification }\end{array}$ & $3 / 2$ & 1 G35W & 0 \\
\hline
\end{tabular}

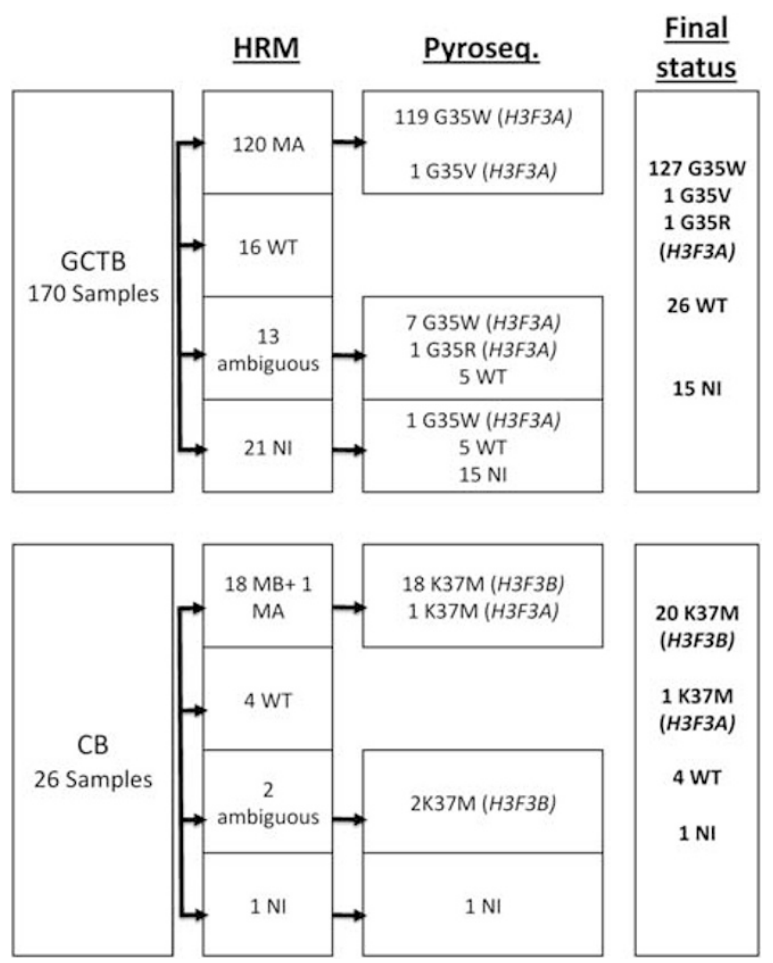

Figure 5 Flow chart of the analysis strategy. CB, chondroblastoma; GCTB, giant cell tumor of the bone; HRM, high resolution melting; MA, mutation of H3F3A; MB, mutation of $H 3 F 3 B$; NI, noninterpretable samples; Pyroseq, pyrosequencing.

tumors of the bone and chondroblastomas groups according to the mutation status.

On histological examination of the 26 wild-type samples of giant cell tumors of the bone, large areas of changes (necrosis, cystic changes or collections of
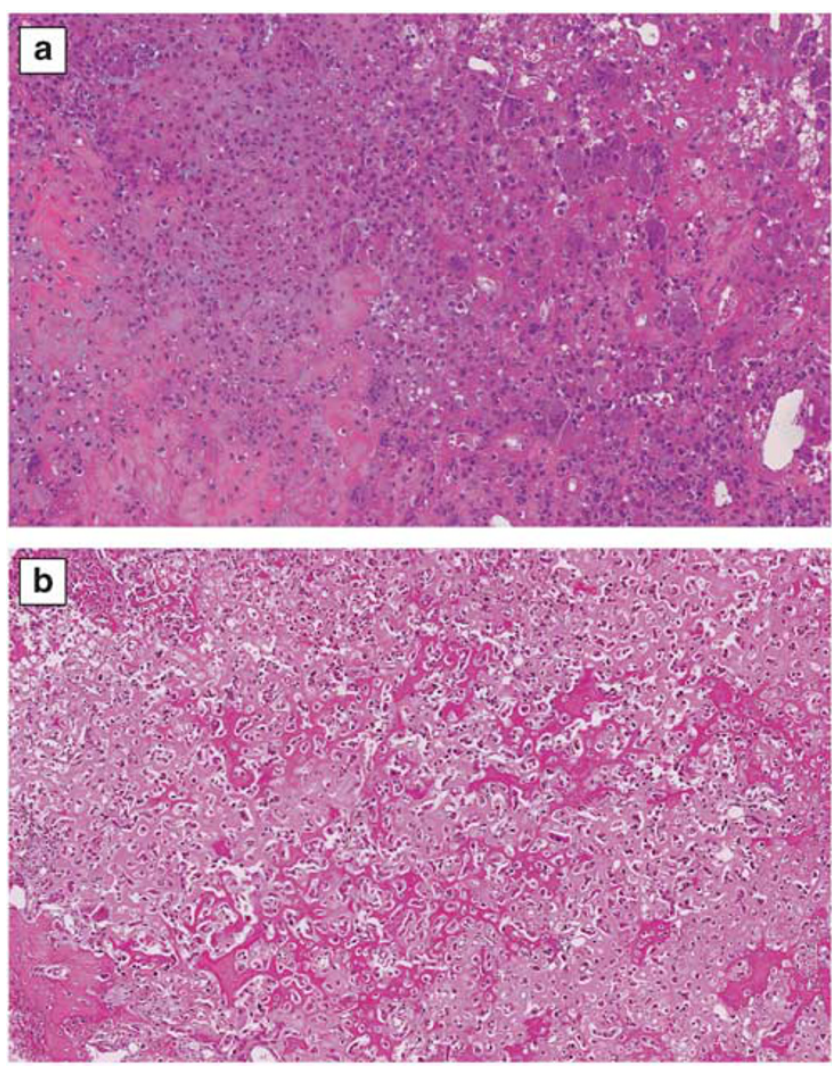

Figure 6 Histological examination of chondroblastoma with dedifferentiated areas: (a) area showing classical features of chondroblastomas (HES x20). (b) Dedifferentiated component with high-grade osteosarcoma features (HES x20).

foamy macrophages involving $>50 \%$ of the tumor) were present in 13 samples (Figure 8), but typical tumor cell areas were found in all cases, permitting diagnosis of giant cell tumors of the bone. 

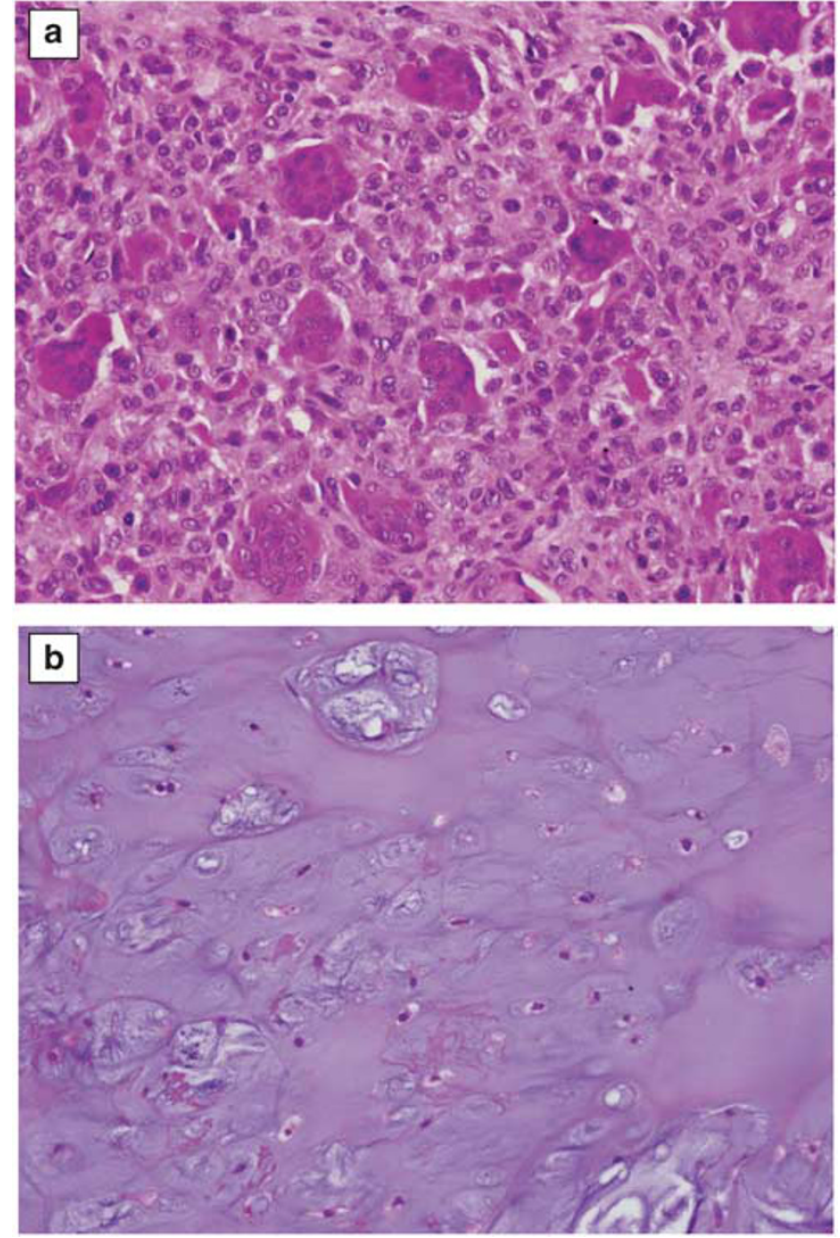

Figure 7 Histological examination of dedifferentiated chondrosarcoma mimicking giant cell tumor of the bone: (a) area showing classical features of giant cell tumors of the bone (HES x40). (b) Cartilaginous component (HES x40).

Three samples exhibited typical morphological features of giant cell tumor of the bone with high mitotic activity and seven samples showed classical giant cell tumors of the bone features without any changes. The last three samples corresponded to giant cell tumors of the bone after denosumab treatment.

After denosumab treatment, giant cell tumors of the bone showed atypical morphological features (Figure 9), consisting of admixtures of fibrous areas with mononuclear spindle cells with areas of ossification and, in some cases, areas still suggesting giant cell tumor of the bone regardless of mutation status.

No relevant features were observed in the chondroblastomas population.

Comparative Study between $\mathrm{H} 3 \mathrm{~F} 3$ Mutation Status and P63 Immunostaining in Giant Cell Tumors of the Bone

P63 status was determined in 58 cases of giant cell tumors of the bone, corresponding to 10 wild-type
Table 4 Clinical features of giant cell tumors of the bone patients according to mutation status

\begin{tabular}{lccc}
\hline & $\begin{array}{c}\text { Wild-type } \\
\text { phenotype }\end{array}$ & $\begin{array}{c}\text { H3F3A } \\
\text { mutation }\end{array}$ & P-value \\
\hline $\begin{array}{l}\text { Number of patients } \\
\text { Sex }\end{array}$ & 19 & 105 & \\
$\quad$ Men & 5 & 52 & \\
$\quad$ Women & 13 & 53 & \\
Mean age & $31.5(11-63)$ & $35(17-61)$ & $P=0.5$ \\
Location & & & $P=0.62$ \\
$\quad$ Lower femoral & 3 & 30 & \\
$\quad$ epiphysis & & & \\
$\quad$ Upper tibial epiphysis & 4 & 18 & \\
$\quad$ Upper humeral & 0 & 2 & \\
$\quad$ epiphysis & & 13 & $P=0.29$ \\
$\begin{array}{l}\text { Pulmonary recurrence } \\
\text { Malignant form }\end{array}$ & 4 & 3 & $P=0.17$ \\
& 2 & 2 & $P=1$ \\
\hline
\end{tabular}

tumors and 48 tumors with $H 3 F 3 A$ mutation. p63 expression was observed in only one of the 10 wildtype tumors tested, and in 30 of the 48 tumors tested associated with mutation $(P<0.04)$. High expression was observed in 9 tumors with mutation and not in wild-type tumors $(P=0.33)$.

\section{Histone H3.3 Lysine K37 Methylation Status}

We investigated the overall methylation status of the H3 histone K37 lysine in the giant cell tumors of the bone, chondroblastomas and control groups (aneurysmal bone cysts and tenosynovial giant cell tumors) using a commercial Elisa assay (Figure 10). No statistically significant difference was found between the giant cell tumors of the bone and chondroblastomas groups compared with the control group $(P=0.34$ and $P=0.21)$. The average methylated histone/total protein ratios were $31.07,47.12$ and $24.94 \mathrm{ng} / \mu \mathrm{g}$ in the giant cell tumors of the bone, chondroblastomas and control groups, respectively. The average ratio was not different between wildtype and mutated giant cell tumors of the bone groups (32.85 vs $30.77 \mathrm{ng} / \mu \mathrm{g}$ ). Moreover, there were marked intra-group variations in methylation level. Elisa tests performed on two separate samples from the same tumor showed different methylation rates.

We then investigated the trimethylation status of lysine K37 more specifically. The results are shown in Figure 11. No statistically significant difference was found between the giant cell tumors of the bone, chondroblastomas and control groups. In the giant cell tumors of the bone and chondroblastomas groups, a low rate of trimethylation did not correlate with a low mutation rate.

\section{IDH Gene Mutations in Giant Cell Tumors of the Bone}

No $I D H-1$ or 2 gene mutations could be detected in any giant cell tumors of the bone sample. We also 
Table 5 Clinical features of chondroblastomas patients according to mutation status

\begin{tabular}{|c|c|c|c|c|}
\hline & Wild-type phenotype & H3F3B mutation & H3F3A mutation & $\mathrm{P}$-value \\
\hline Number of patients & 3 & 20 & 1 & \\
\hline Sex & & & & $P=0.62$ \\
\hline Men & 1 & 13 & 1 & \\
\hline Women & 2 & 7 & 0 & \\
\hline Mean age & $22(17-31)$ & $20.75(13-60)$ & 46 & $P=0.29$ \\
\hline Location & & & & $P=1$ \\
\hline Lower femoral epiphysis & 1 & 5 & 0 & \\
\hline Upper tibial epiphysis & 1 & 4 & 1 & \\
\hline Upper humeral epiphysis & 0 & 2 & 0 & \\
\hline Local recurrence & 0 & 1 & 1 & $P=0.094$ \\
\hline Pulmonary implants & 0 & 0 & 0 & $P=1$ \\
\hline Malignant form & 0 & 0 & 1 & $P=0.042$ \\
\hline
\end{tabular}
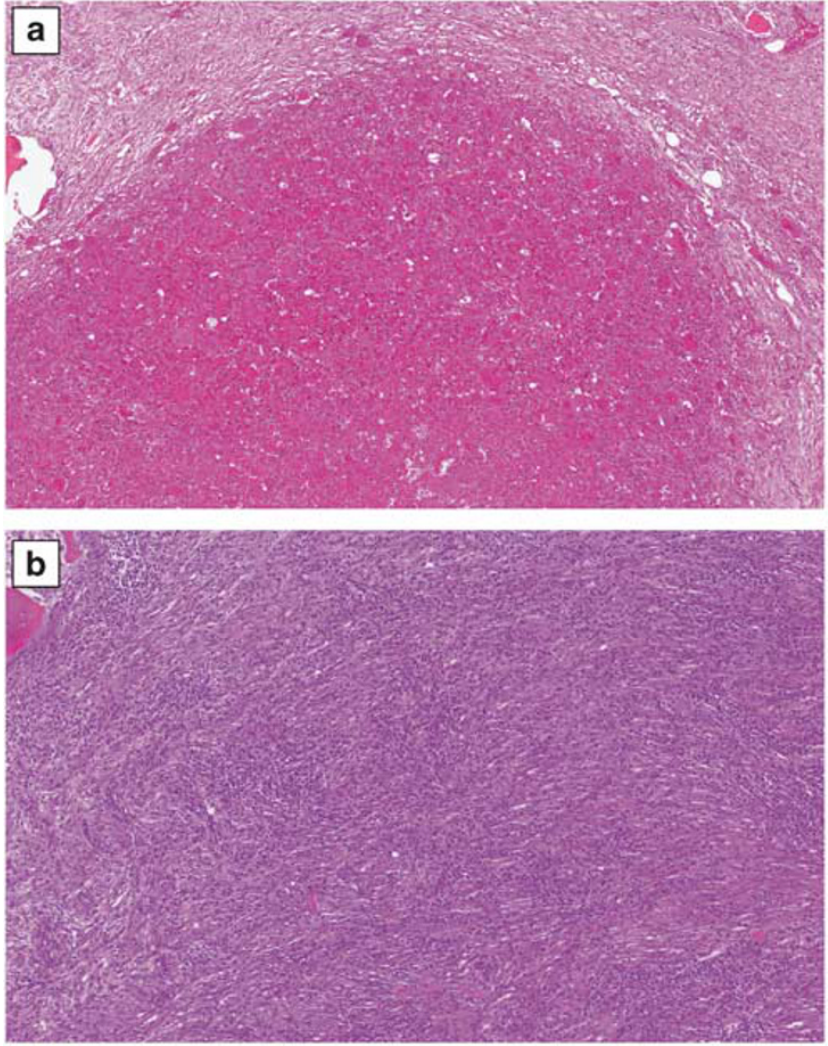

Figure 8 Histological examination of wild-type giant cell tumors of the bone: (a) area with classical features of giant cell tumors of the bone (HES x10). (b) Area with mononuclear spindle cell component (HES x10).

failed to find $I D H$ mutations in giant cell-rich or cartilaginous components of the three cases of dedifferentiated chondrosarcoma mimicking giant cell tumor of the bone.

\section{Discussion}

As previously reported, ${ }^{14}$ we confirmed the high prevalence of $H 3 F 3 A$ and $H 3 F 3 B$ gene mutations in

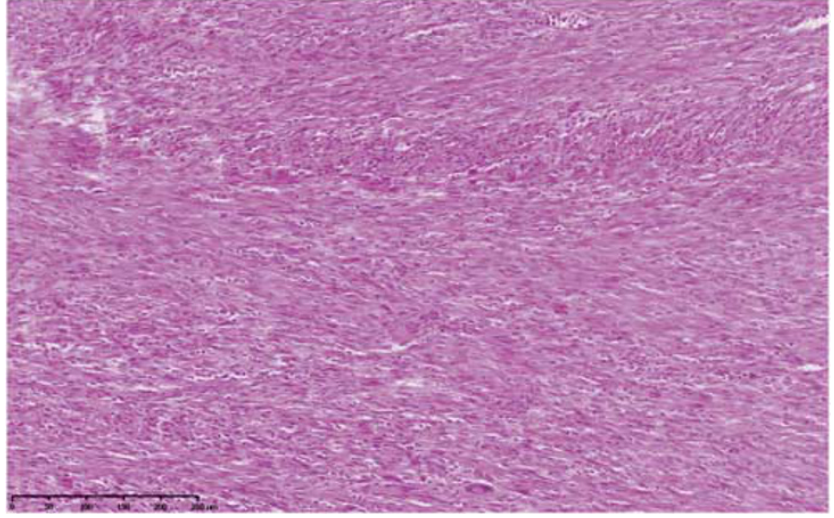

Figure 9 Histological examination of wild-type giant cell tumors of the bone after denosumab treatment (the prior biopsy showed a $H 3 F 3 A$ mutation): mononuclear spindle cell component combined with fibrous changes (HES x10).

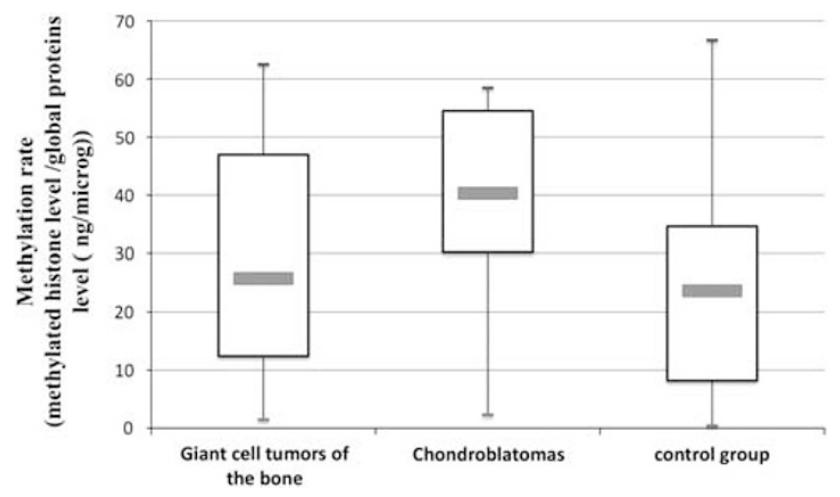

Figure 10 Overall methylation levels of H3 histone K37 in giant cell tumors of the bone, chondroblastomas and control groups.

giant cell tumors of the bone and chondroblastomas patients (85\% and $88 \%$, respectively). The lack of these mutations in the most common other giant cellrich and epiphyseal bone lesions suggest the use of detection of $\mathrm{H} 3 \mathrm{~F} 3$ mutation as a diagnostic tool in current practice. Moreover, this study showed that a 


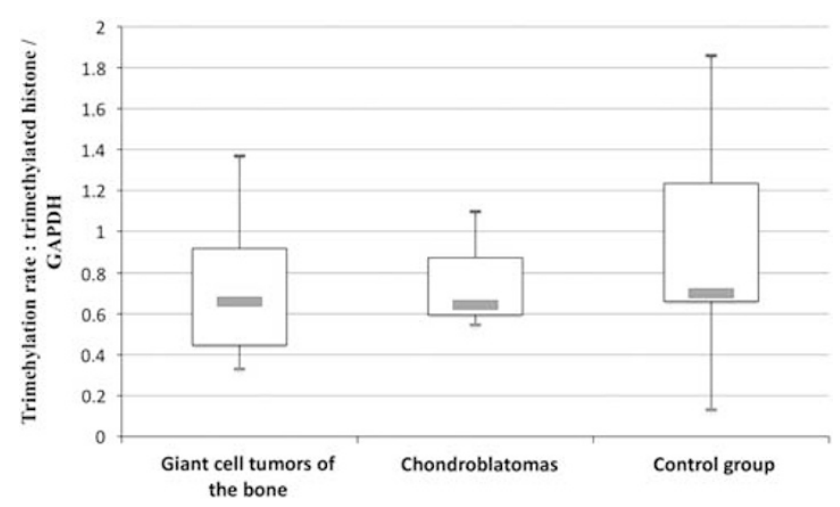

Figure 11 Trimethylation levels of H3 histone K37 lysine in giant cell tumors of the bone, chondroblastomas and control groups.

H3F3 mutation search is a very sensitive diagnostic tool for giant cell tumors of the bone in scarce fineneedle biopsy material, with a mutation rate of $90 \%$. Although there were no significant differences in mutation rate between the three groups sampled $(P=0.78)$, there was an upward trend in the core needle biopsy samples compared with the surgical specimen group. This suggested that undertaking molecular analysis probably depended on the preanalytic treatment rather than on the number of tumor cells. Indeed, the fixation and decalcification protocols for core needle samples are probably more homogenous and better suited to molecular biology than those applied to surgical specimens.

Our results are in accordance with previous studies, which found $\mathrm{H} 3 \mathrm{~F} 3$ gene mutations in $69-96 \%$ of giant cell tumors of the bone ${ }^{14,15}$ and in $70-100 \%$ of chondroblastomas. ${ }^{14,15}$ Although nextgeneration sequencing has been used to identify H3F3 mutations, ${ }^{14}$ its use has to date been restricted to a small number of hospital centers, mainly for research purposes. Our aim was to establish a simple, inexpensive diagnostic tool for routine practice and we developed a pyrosequencing test to rapidly confirm and characterize the cases for which high resolution melting was suggestive. In terms of sensitivity, pyrosequencing performed better than Sanger sequencing for the samples with low mutation rates $(12 \%)$.

The technique revealed two rare $H 3 F 3 A$ mutations in giant cell tumors of the bone: one G35V and one G35R mutation. No specific clinical-specific features were observed in these two patients. G35V mutation has only been reported in two earlier publications (two cases of giant cell tumors of the bone) ${ }^{15}$ and G35R mutation in one case of conventional osteosarcoma and one case of giant cell tumor of the bone. ${ }^{10,14}$

Interestingly, a G35W H3F3A mutation was detected in two of the three cases of dedifferentiated chondrosarcoma mimicking giant cell tumor of the bone studied. The third case was not interpretable, probably because of a long-term decalcification process. The six cases in the control group of conventional central dedifferentiated chondrosarcomas were all negative for H3F3 mutations. To our knowledge, only six patients with this entity have been reported in the literature (Table 6) and tumors were mainly located in the proximal humerus $(n=4)$. One of the patients presented with metastases, and local recurrence occurred in two cases. In our study, long-term follow-up data (10 years) were available for one patient. This tumor did not exhibit a radioclinical presentation suggestive of giant cell tumors of the bone, but had an acetabular location, more suggestive of a cartilaginous tumor. It did not recur after conservative surgery by curettage. In the second case of dedifferentiated chondrosarcoma mimicking giant cell tumor of the bone, the tumor was located in the upper femoral epiphysis and no relapse occurred within 40 months follow-up. The indolent clinical course and the presence of H3F3A mutations in these two cases suggested that this entity may be linked to giant cell tumors of the bone rather than to dedifferentiated chondrosarcoma, especially as the search for mutations in IDH1-IDH2 was negative in both cases. Presneau et $a 1^{14}$ recently described an IDH2 mutation and no H3F3 mutation in an osteoclast-rich tumor with small fragments of neoplastic cartilaginous tissue. The authors reclassified the tumor as dedifferentiated chondrosarcoma with dedifferentiated areas of osteoclast-rich sarcoma rather than a real dedifferentiated chondrosarcoma mimicking giant cell tumor of the bone. IDH2 mutations were described in a series of giant cell tumors of the bone. ${ }^{11}$ However, we did not find any IDH mutations in our series, but these divergent results suggest the need for further explorations in this very rare subtype of bone tumor. The hypothesis that dedifferentiated chondrosarcoma mimicking giant cell tumor of the bone may constitute an heterogeneous tumor group, including cases of giant cell tumors of the bone with foci of cartilaginous differentiation, which show H3F3 mutations, and true dedifferentiated chondrosarcomas with giant cell tumors of the bone features, which can show IDH mutation, cannot be excluded.

We also report here the H3F3 mutational status of a tumor combining typical areas of chondroblastoma and areas of high-grade conventional osteosarcoma, with a sudden transition between the two components. In view of these tumors, very few cases of which have been described in the literature, ${ }^{16,17}$ the diagnosis of malignant chondroblastoma rather than chondroblastoma-like osteosarcoma could be raised. This sample exhibited a rare mutation of $H 3 F 3 A$ (K37M), never to our knowledge described in the other giant cell-rich tumors. Molecular analyses of more samples would be necessary to determine whether a K37M H3F3A mutation may be specific to this entity. The identification of this mutation, combined with the morphological features of the tumor and sudden transition between its two components, which seemed to be juxtaposed, led us to 
Table 6 Lists of cases of dedifferentiated chondrosarcoma mimicking giant cell tumor of the bone reported in the literature

\begin{tabular}{|c|c|c|c|c|c|c|}
\hline Authors & Journals & Number of cases & Local recurrence & Metastasis & Aftercare (months) & Genetic study \\
\hline Knösel et $a l^{30}$ & Pathol Res Pract & 1 & No & No & 10 & DU \\
\hline Huang et $a l^{31}$ & Int J Surg Pathol & 1 & No & No & DU & No \\
\hline Arora et al32 & Indian J Pathol Microbiol & 1 & No & No & 10 & No \\
\hline Estrada et $a l^{33}$ & Ann Diagn Pathol & 1 & No & No & 5 & No \\
\hline Ishida et $a l^{34}$ & Skeletal Radiol & 1 & Yes & No & 9 & No \\
\hline Sissons et $a l^{35}$ & J Bone Joint Surg Am & 1 & Yes & DU & 102 & No \\
\hline
\end{tabular}

Abbreviation: DU, data unavailable.

classify this tumor as a dedifferentiated malignant chondroblastoma.

As recently described, ${ }^{18}$ the mutation we observed in both the cases of malignant dedifferentiated giant cell tumors of the bone included in this study was the more common G35W H3F3A mutation and did not allow us to distinguish conventional from malignant forms of giant cell tumors of the bone.

To our knowledge, no publication has previously tried to correlate the H3F3 mutation status and clinical data. In our study, we did not find any statistically significant differences between the two groups of mutated and wild giant cell tumors of the bone, particularly in terms of local recurrence and pulmonary implants. H3F3A mutations thus seem to have no prognostic value. However, the small number of wild-type giant cell tumors of the bone patients $(n=19)$ is probably a restrictive factor and these results should be confirmed on a larger wildtype giant cell tumors of the bone series.

On histological examination, about half of the wild-type giant cell tumors of the bone samples showed significant changes, including in particular large fibrous and cystic areas. Core sampling on unchanged tumors suggestive of giant cell tumors of the bone found only one additional H3F3 mutation. The other half of the wild-type tumor samples showed typical giant cell tumors of the bone features, sometimes associated with a high mitotic rate. These findings support the hypothesis that wild-type status cannot be completely explained by the presence of extensive fibrous and cystic tumor changes or by a lack of sensitivity of the molecular analysis, and suggest that a small subset of bone tumors exists with anatomo-pathological features of giant cell tumors of the bone and a different biological background.

Similarly, we showed here that p63 overexpression is strongly associated with $\mathrm{H} 3 \mathrm{~F} 3$ mutations $(P<0.04)$. Interestingly, most of the $H 3 F 3$ wild-type giant cell tumors of the bone were also negative for p63 on immunohistochemical study, suggesting again the existence of a particular subtype of wild-

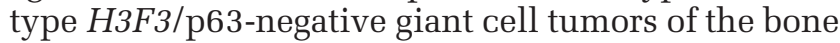
with possibly different molecular and biological features.

Among giant cell tumors of the bone obtained after treatment with denosumab, most of the samples showed large areas of fibrous change and reactive osteogenesis associated with a mononuclear spindle cell component and, in some cases, with residual giant cells. In contrast to a previous publication, ${ }^{19}$ which described conservation of mutation after denosumab treatment, a loss of mutated cells after denosumab treatment was noted in two patients in our cohort. We failed to show any correlation between histology and molecular analysis in these cases. Indeed, major morphological changes were also observed in tumors with conserved mutation.

The molecular mechanisms underlying the effects of $H 3 F 3$ mutations in giant cell tumors of the bone are not yet understood. Histone proteins have a major role in chromatin compaction, which in turn controls gene transcription. H3.3 belong to the large histone H3 family, and its peptidic sequence differs by only five amino acids from the H3.1 sequence. ${ }^{20}$ H3.3 is specifically integrated into telomeric and pericentromeric chromatin. ${ }^{21}$ Telomeric modifications have been known in giant cell tumors of the bone for a long time. ${ }^{12,22}$ H3F3A mutations, in particular K28M and G35R, have also been reported in pediatric multiform glioblastoma, in combination with telomeric changes. ${ }^{23}$

All H3F3 mutations $(28,35$ and 37) are located at the N-terminal histone tail, a domain well known as a regulatory region. Indeed, several post-translational modifications of the histone tail (methylation, acetylation, phosphorylation) have been reported to affect gene transcription. ${ }^{24}$ The impact of K27M H3F3A gene mutation has already been investigated in pediatric glial tumors ${ }^{25}$ and the loss of K27 trimethylation has been confirmed. In giant cell tumors of the bone and chondroblastomas, G35 and K37 mutations possibly affect post-translational modification of amino-acid residues located near the mutation locus.

Lysine K37 is known to be the target of methylase and demethylase, ${ }^{24}$ and permanent K37 trimethylated status is known to be a transcriptional activator and is involved in the pathogenesis of some epithelial tumors. ${ }^{26}$ Although no post-translational modifications have been described on glycine G35, some authors ${ }^{27}$ have shown that G35 is a critical residue of the K37 demethylase active site and has a key role in recognition between histone and this enzyme. In this context, we hypothesized that the G35W H3F3 mutation affects recognition between 
the histone and demethylase and may lead to a permanent methylated status of lysine K37, which can be a major mechanism in oncogenesis. As previously reported, ${ }^{15}$ we tried to detect methylation changes using immunohistochemistry staining. As all fixed FFPE tumor samples included in this study were subjected to a decalcification procedure, following various protocols, we failed to obtain reliable staining. In contrast to Bovée et al who also used formic acid decalcification, we concluded that staining variations were more probably due to the decalcification protocol than tumor antigen expression and that the evaluation of methylation status by immunochemistry cannot be a useful tool in current practice in the context of giant cell-rich tumors of bones.

We also performed a global K37 methylation quantification assay and trimethylation status study of H3 lysine K37. No statistically significant difference was found between mutated tumors and controls. These results can be explained in two ways. G35 and K37 may have no effect on methylation of residue 37 but affect post-translational modifications of other residues such as isomerization proline on position 31, which are the only H3.3specific residues near the mutation site, or they may have affected other post-translational modifications of amino-acid 37 such as acetylation. ${ }^{28}$

We observed that the overall methylation rate was highly variable and had a tendency to be increased in giant cell tumors of the bone and chondroblastomas compared with aneurysmal bone cysts and tenosynovial giant cell tumors. These results together showed that variations in the methylation rate more probably reflect a high transcriptional activity level than a mechanistic consequence of the mutation. This finding is probably consistent with the results of Cleven et $a 1^{15}$ that showed that the methylation rate in giant cell tumors of the bone was not always correlated with mutation status.

As no giant cell tumor of the bone cell lines, and thus no pure tumor cell extracts, were available, we analyzed frozen giant cell tumors of the bone samples. We therefore cannot exclude the possibility that we failed to show statistically significant differences between our tumors and the control group because of the heterogeneous nature of the cellularity within a giant cell tumor of the bone sample in which, in addition to true mononuclear tumor cells, there were varying proportions of osteoclastic-like giant cells and inflammatory cells. The latter component may have limited our assay performance.

Given these results, methylation rates do not appear to be a useful diagnostic tool in current practice.

Kaneko et $a l^{11}$ recently identified a IDH2 R172S mutation in $80 \%$ of giant cell tumors of the bone. In our giant cell tumors of the bone cohort, we could not detect any mutation of the $I D H$ genes, a result consistent with the study of Presneau et al. ${ }^{14}$ Nevertheless, some authors have reported Asian giant cell tumors of the bone specificity, ${ }^{29}$ with a high prevalence of this tumor in Chinese and Indian populations. These features may explain the different genetic results, reflecting different physiopathological processes.

To conclude, our findings confirm the high performance of $H 3 F 3 A$ and $H 3 F 3 B$ gene analysis as a diagnostic tool for giant cell tumors of the bone and chondroblastomas. This biological analysis may be of great value in challenging cases and/or with small samples. In our study, $90 \%$ of our core needle biopsy samples showed H3F3A mutations. For a cost-effective approach, we propose high resolution melting screening followed by pyrosequencing to determine and confirm mutations.

With greater numbers of cases studied, these new markers will allow better classification of rare tumor entities, particularly dedifferentiated chondrosarcoma mimicking giant cell tumor of the bone and dedifferentiated chondroblastomas. On the other hand, one exciting prospect opened by this study is the better characterization of the subset of wild-type giant cell tumors of the bone identified without p63 expression.

The oncogenic mechanisms of H3F3 mutations remain unclear but they are probably linked to posttranslational changes in the H3F3 N-terminal tail.

\section{Acknowledgments}

The authors would like to express their sincerest thanks to AS Neumann, B Brosse and B Sevin for their help and contributions. All our support came from National Public Institutions: University Hospital of Tours.

\section{Disclosure/conflict of interest}

The authors declare no conflict of interest.

\section{References}

1 Athanasou NA, Bansal M, Forsyth R, et al. Giant cell tumour of the bone. In: Fletcher CDM, Bridge JA, Hogendoorn PC, et al. (eds) World Health Organization Classification of Tumours of Soft Tissue and Bone, 4th edn. International Agency for Research on Cancer: Lyon, France, 2013, pp 321-324.

2 Gao Z, Yin J, Xie X, et al. Local control of giant cell tumors of the long bone after aggressive curettage with and without bone cement. BMC Musculoskelet Disord 2014;15:330.

3 Ramappa AJ, Lee FY, Tang P, et al. Chondroblastoma of bone. J Bone Joint Surg Am 2000;82-A:1140-1145.

4 Moriceau G, Ory B, Gobin B, et al. Therapeutic approach of primary bone tumours by bisphosphonates. Curr Pharm Des 2010;16:2981-2987.

5 Chawla S, Henshaw R, Seeger L, et al. Safety and efficacy of denosumab for adults and skeletally mature adolescents with giant cell tumour of bone: interim analysis of an open-label, parallel-group, phase 2 study. Lancet Oncol 2013;14:901-908. 
6 Muheremu A, Niu X. Pulmonary metastasis of giant cell tumor of bones. World J Surg Oncol 2014;12:261-269.

7 Viswanathan S, Jambhekar NA, Merchant NH, et al. Chondroblastoma of bone-not a 'benign disease': clinico-pathologic observations on sixty cases. Indian J Pathol Microbiol 2004;47:198-201.

8 Anract P, De Pinieux G, Cottias P, et al. Malignant giant-cell tumours of bone. Int Orthop 1998;22:19-26.

9 Maues De Paula A, Vasiljevic A, Giorgi R, et al. A diagnosis of giant cell-rich tumour of bone is supported by p63 immunohistochemistry, when more than 50\% of cells is stained. Virchows Arch 2014;465:487-494.

10 Behjati S, Tarpey PS, Presneau N, et al. Distinct H3F3A and H3F3B driver variants define chondroblastoma and giant cell tumour of bone. Nat Genet 2013;45:1479-1482.

11 Kato Kaneko M, Liu X, Oki H, et al. Isocitrate dehydrogenase mutation is frequently observed in giant cell tumor of bone. Cancer Sci 2014;105:744-748.

12 Forsyth R, De Boeck G, Bekaert S, et al. Telomere biology in giant cell tumour of bone. J Pathol 2008;214: $555-563$.

13 Ogino S, Gulley ML, den Dunnen JT, et al. Association for molecular patholpogy training and education committtee. Standard mutation nomenclature in molecular diagnostics: practical and educational challenges. J Mol Diagn 2007;9:1-6.

14 Presneau N, Baumhoer D, Behjati S, et al. Diagnostic value of H3F3A mutations in giant cell tumour of bone compared to osteoclast-rich mimics. J Pathol Clin Res 2015;1:113-123.

15 Cleven AHG, Höcker S, Briaire-de Bruijn I, et al. Mutation analysis of H3F3A and H3F3B as a diagnostic tool for giant cell tumor of bone and chondroblastoma. Am J Surg Pathol 2015;39:1576-1583.

16 Martin KL, Firestone DE, McGarry SV, et al. Chondroblastoma-like osteosarcoma. Pathol Int 2014;64: 409-411.

17 Aycan OE, Vanel D, Righi A, et al. Chondroblastomalike osteosarcoma: a case report and review. Skeletal Radiol 2014;44:869-873.

18 Sarungbam J, Agaram N, Hwang S, et al. Symplastic/ pseudoanaplastic giant cell tumor of the bone. Skeletal Radiol 2016;45:929-935.

19 Girolami I, Mancini I, Simoni A, et al. Denosumab treated giant cell tumour of bone: a morphological, immunohistochemical and molecular analysis of a series. J Clin Pathol 2015;69:240-247.

20 Hake SB, Allis CD. Histone H3 variants and their potential role in indexing mammalian genomes: the ' $\mathrm{H} 3$ barcode hypothesis'. Proc Natl Acad Sci USA 2006;103: 6428-6435.

21 Wong LH, McGhie JD, Sim M, et al. ATRX interacts with H3.3 in maintaining telomere structural integrity in pluripotent embryonic stem cells. Genome Res 2010;20:351-360.

22 Matsuo T, Hiyama E, Sugita T, et al. Telomerase activity in giant cell tumors of bone. Ann Surg Oncol 2007;14:2896-2902.

23 Schwartzentruber J, Korshunov A, Liu X-Y, et al. Driver mutations in histone H3.3 and chromatin remodelling genes in paediatric glioblastoma. Nature 2012;482: 226-231.

24 Berger SL. The complex language of chromatin regulation during transcription. Nature 2007;447: 407-412.

25 Chan K-M, Fang D, Gan H, et al. The histone H3.3K27M mutation in pediatric glioma reprograms H3K27 methylation and gene expression. Genes Dev 2013;27: 985-990.

26 Frescas D, Guardavaccaro D, Kuchay SM, et al. KDM2A represses transcription of centromeric satellite repeats and maintains the heterochromatic state. Cell Cycle Georget Tex 2008;7:3539-3547.

27 Cheng Z, Cheung P, Kuo AJ, et al. A molecular threading mechanism underlies Jumonji lysine demethylase KDM2A regulation of methylated H3K36. Genes Dev 2014;28:1758-1771.

28 Morris SA, Rao B, Garcia BA, et al. Identification of histone H3 lysine 36 acetylation as a highly conserved histone modification. J Biol Chem 2007;282: 7632-7640.

29 Saikia KC, Bhuyan SK, Borgohain M, et al. Giant cell tumour of bone: an analysis of 139 Indian patients. J Orthop Sci 2011;16:581-588.

30 Knösel T, Werner M, Jung A, et al. Dedifferentiated chondrosarcoma mimicking a giant cell tumor. Is this low grade dedifferentiated chondrosarcoma? Pathol Res Pract 2014;210:194-197.

31 Huang J, Jiang Z, Yang Q, et al. Benign looking giant cell component in dedifferentiated chondrosarcoma: benign or malignant? A case report. Int J Surg Pathol 2013;21:48-53.

32 Arora R, Sharma A, Dinda AK. Dedifferentiated chondrosarcoma of the femur mimicking a conventional giant cell tumor: a diagnostic pitfall. Indian J Pathol Microbiol 2008;51:561.

33 Estrada EG, Ayala AG, Lewis V, et al. Dedifferentiated chondrosarcoma with a noncartilaginous component mimicking a conventional giant cell tumor of bone. Ann Diagn Pathol 2002;6:159-163.

34 Ishida T, Dorfman HD, Habermann ET. Dedifferentiated chondrosarcoma of humerus with giant cell tumor-like features. Skeletal Radiol 1995;24:76-80.

35 Sissons HA, Matlen JA, Lewis MM. Dedifferentiated chondrosarcoma. Report of an unusual case. J Bone Joint Surg Am 1991;73:294-300.

Supplementary Information accompanies the paper on Modern Pathology website (http://www.nature.com/ modpathol) 